\title{
Demonstration of Sovereignty Entitlement of Diaoyu Islands from the Perspective of Treaty Law: According to Vienna Convention on the Law of Treaties
}

\author{
Kani Su \\ Law School of Fujian Normal University, Fuzhou Fujian, 350108, China
}

Keywords: Law of Treaties, Sovereignty of Diaoyu Island, Vienna Convention on the Law of Treaties.

\begin{abstract}
Interpretation and application of treaties is important to resolve territorial sovereignty disputes as we want to prove Diaoyu Islands sovereignty entitlement. We need not only to research some relevant historical documents related to the islands, but also to arrange and demonstrate relevant treaties juridical logic. China should not ignore the reality and significance of legal method to resolve some international disputes because International Law rules become more and more important this day. It is an important path for China to demonstrate Diaoyu Islands sovereignty entitlement according to the rules about interpretation, validity, application of conflicting in VCLT.
\end{abstract}

\section{Introduction}

In 2017, China has established relationship with Japan for 45 years, which should be a joyful event. However, because of the right-wing forces in Japan, the sovereignty of Diaoyu Island has obviously become the obstacle hindering the further development of two countries. The policy of "shelve disputes and carry out joint development” put forward by Chinese former leader has been confronted by challenges once more. Recently, Japan has revised textbooks of elementary and secondary schools, which claims Diaoyu Island to be its "inherent territory" and puts forward the argument that "There is no territory problem" between China and Japan. At present, there is still certain elastic space for China and Japan to solve the sovereignty of Diaoyu Island by diplomacy. However, there are no obvious effects. By building airports, lighthouse, "nationalization” and revising textbooks, Japan has tried to create a false impression of "actual control" on the international society, so as to bring pressure for China's defending for the sovereignty of Diaoyu Island. To solve the distribute of Diaoyu Island by force, the United Nations will focus on and intervene in it. It is a sound strategy to solve the distribute peacefully on the basis of respecting each other's sovereignty. Therefore, although there is certain risk to solve the sovereignty of Diaoyu Island by law, China is not totally passive after fully preparing the historical foundation and legal basis, which proves that the sovereignty of the Diaoyu Island belongs to China. Moreover, after the Philippines provoked "the South China Sea Arbitration", China will face more complicated situations as territorial sovereignty and disputed maritime regions. Thus China has to actively cope with these problems in advance. In addition to prove that the sovereignty of Diaoyu Island belongs to China from the perspective of history, China has to analyze and explain relevant treaties from the perspective of Law of Treaties, which should demonstrate that, as the affiliated island of Taiwan, the sovereignty of Diaoyu Island was returned to China together with the sovereignty of Taiwan after World War II. Japan has no legal right of Diaoyu Island any more. Without the permission of China, America has no right to "dispose" the "administration right" of Diaoyu Island. From the perspective of explanation of Law of Treaties, effect and conflict application, this paper discusses that the sovereignty of Diaoyu Island belongs to China, which offers certain references for China to solve the distributes of Diaoyu Island and South China Sea by law.

Vienna Convention on the Law of Treaties of 1969(hereinafter referred to as Law of Treaties) is the academic achievement of United Nations International Law Commission. Although the Law of Treaties is not retroactive, it is the complication of customary rules of previous conclusion fields, which is formulated by cooperating with the objective of United Nations Charter. Therefore, while 
explaining relevant validity and contents of treaties, both China and Japan can take validity of treaties, explanation and rule to solve conflicts in Law of Treaties as the applicable or referential legal basis.

\section{International Treaties Referring to the Sovereignty of Diaoyu Island}

Before the Sino- Japanese War of 1894-1895, China obtained the sovereignty of Diaoyu Island on the basis of "preoccupation", which conformed to the rule of territorial acquisition of International Law. Historians have already fully discussed about that. However, with the agreement of Treaty of Shimonoseki between China and Japan in 1895, Diaoyu Island was ceded to Japan as the affiliated island to Taiwan, further to unveil the prelude China and Japan fighting for the sovereignty of Diaoyu Island. As a matter of fact, among all disputes of the sovereignty of Diaoyu Island, it focuses on the validity confirmation, interpretation and application of treaties on Taiwan and Ryukyu Islands around the World War II. It is inevitable that legal argumentation on the sovereignty of Diaoyu Island should be developed around these treaties.

\subsection{Sino-Japan Treaty of Shimonoseki in 1895}

With the disastrous defeat of China in Sino-Japanese naval battle, the Qing government was forced to sign the Treaty of Maguan (named as Treaty of Shimonoseki) of national betrayal and humiliation in Japanese Shunpanro Shimonoseki on April, 17, 1895. Of which, treaties related to Taiwan was the second treaty: "China will cede the authority of Xiakai and all fortresses,military factories and all public objects to Japan forever: 1) (Liaodong Peninsula). 2) Taiwan and all affiliated islands. 3) (Penghu islands)". (1)

It is considered as the treaty that Diaoyu Island was ceded to Japan. That's because Diaoyu Island was marked on Chinese coast defense chart as the affiliated island to Taiwan in period of Ming and Qing Dynasty. (2)

\subsection{Sino- American-British Cairo Declaration in 1943}

After World War II got the decisive victory in 1943, leaders of China, America and Britain held a meeting in Cairo, for the purpose of discussing about the common military problem of fighting against Japan and how to deal with Japan after the war. After the meeting, the famous Cairo Declaration was published. Although it is as short as 200 words, it has clearly stipulated obligations and responsibilities of three countries, (3)which clearly expresses that the sovereignty of Manchu, Taiwan and Penghu Islands ceded to Japan must be returned to China.

\subsection{Sino-Soviet-American-Britain Potsdam Declaration in 1945}

On July 17th, 1945, leaders of Soviet, America and Britain held a meeting in the suburb of Berlin Potsdam. During the meeting, they delivered an ultimatum to Japan, namely the Potsdam Declaration that China, America and Britain urged Japan to surrender. The declaration was drafted by America and agreed by Britain. Although China did not participated in the meeting, Chiang Kai-shek expressed his consent before the publication of declaration.

\subsection{Japan signed Japanese Instrument of Surrender with allied nations in 1945}

On Sept. 2nd, 1945, Japan officially surrendered to anti-fascist allied nations. According to the Japanese Instrument of Surrender signed on American "Missouri" warship in Tokyo Bay, Japan unconditionally accepted the stipulations of Potsdam Declaration, and promised to take all measures and issue orders to implement obligations of the declaration.

\subsection{Japanese Instrument of Surrender submitted to China in 1945}

On Sept. 9th, 1945, Japan surrendered to Chinese government in Nanjing and submitted its Instrument of Surrender to China, which clearly expressed that Japan would return territories of Taiwan to China. 


\subsection{American-Japanese San Francisco Peace Treaty in 1951}

On Sept. 4th, 1951, peace conference with Japan joined by 51 nations was inaugurated in San Francisco. Most of these nations were those South American countries and Western European countries that did not actually fight against Japan. However, China, which sacrificed most and made special contributions to defeat Japanese fascists, was excluded from the conference. On Sept. 8th, representatives of 49 countries signed on the Peace Treaty with Japan, but three representatives from Soviet, Poland and Czechoslovakia refused to sign the treaty. The treaty announced that Japan terminated the state of war with all allied countries, and then cooperated with all counties equally and peacefully.

\subsection{American- Japanese Okinawa Reversion Treaty in 1971}

On June 17th, 1971, Okinawa Reversion Treaty(the full name is Agreement on Ryukyu Islands and Daito Islands) was signed in Washington and Tokyo at the same time. On that basis, America declared to "return" the "authority” over Diaoyu islands to Japan. Thus Japan "took over” Ryukyu Islands and renamed it as "Okinawa Prefecture". Diaoyu Islands was changed as "Senkaku islands", which was under the jurisdiction of "Okinawa Prefecture”.

\subsection{Sino- Japanese Joint Declaration}

In 1972, Sino- Japanese Joint Declaration resumed the diplomatic relations between two countries, which declared that: "Taiwan is an integral part of territory of the People's Republic of China. Japanese government fully understands and respects the standpoint of Chinese government, and also insists on following the 8th treaty of Potsdam Declaration.”

\section{Argumentation on Diaoyu Island Belonging to "Affiliated Island” of Taiwan from the “well-intention interpretation” Principle of Law of Treaties}

During the process of application, various problems will inevitably appear as treaties come into force, especially those treaties involving the territorial sovereignty. Because of oversimplified principle or ambiguity of those treaties, and also the dynamic changes around the agreement of contracting parties, it is extremely easy to result in divergence of application. Therefore, how to eliminate the ambiguity between contracting parties to the largest extent by treaties has become an extremely important content in the Law of Treaties.

Among the above treaties, there is no specific treaty containing the word of "Diaoyu Island". Consequently, the key of dispute over the sovereignty of Diaoyu Island between China and Japan lies in whether the "Diaoyu Island" belongs to the "affiliated island" of Taiwan. Besides, whether the geographical range of "administration" returned to Japan by America includes the "Diaoyu Island".Therefore, whether the Diaoyu Island is included in the scope of "Taiwan" or "the affiliated island of Taiwan" ceded to Japan, by combining with the objective of all related treaties, it needs to make rational presumption of both parties' intention on the basis of respecting the objective historical facts. Besides, it cannot result in malicious damages to contracting parties.

The Diaoyu Island and its affiliated islands disperse over northern latitude $25^{\circ} 40^{\prime} \sim 26^{\circ}$ and east longitude $123^{\circ} \sim 124^{\circ} 34^{\prime}$. (4) In San Francisco Peace Treaty of 1951, America proposed that Japanese regions hosted by UN were specified as "Nansei Islands to the south of 29 degrees north latitude, southern islands to the south of Lot's Wife island, Okinotorishima and Minami-Tori Shima”, which did not involve the geographical locations of Diaoyu Island or the affiliated islands at all.

Above all, from the Principles of International Law of "Treaty Obligation", to fulfill the obligations of treaties kindly should take the "well-intention interpretation" as the precondition. Otherwise, if the contracting party or the third party maliciously distorts or interprets treaties, it will absolutely result in malicious fulfillment of treaties. 


\section{Argumentation on the Illegality of Diaoyu Island's “Administration” by America and Japan from the "Relative Potency" Principle of Law of Treaties}

Only under the premise of legal and effective treaties, the principle of "Paeta Sunt Servanda" can restrain the contracting parties. Illegal or invalid treaties cannot restrain the contracting parties, let alone directly restrain the third parties. Among the above treaties or international documents, there are not so many treaties involving China or Japan as the direct contracting parties. On the contrary, a lot of treaties set corresponding obligations or rights for Japan or China as the non-direct contracting parties. As a matter of fact, with more and more circumstances of mutual reliance in modern international society, International Law does not oppose the settlement of rights or obligations for the third party in treaties. However, it should belong to the exceptional circumstances that "the third country cannot be restrained by treaty". International Law Commission considers that the international society has got general consensus for the normal rules.

Although Japan is not the direct contracting party of Cairo Declaration or Potsdam Declaration, International Law also accepts the exceptional circumstance that the contracting party sets rights or obligations for the third party. In addition, as the non-contracting country of San Francisco Peace Treaty, whether China has accepted the obligations of treaties involving "Chinese relevant rights and interests”? According to Declaration of the United Nations and Declaration on Universal Security by Four Governments, as one of victorious nations playing a key role among allied nations during World War II and leading to the victory of War of Resistance Against Japan, China should deal with affairs of treaties against enemy together with other allied nations after the war. Although the conditions of the civil war makes the recognition of contracting parties become more complicated, allied nations should choose Chinese government to negotiate the postwar affairs, which is an effective representative in International Law. Therefore, no matter the San Francisco Peace Treaty, or the Okinawa Reversion Treaty, China has never clearly accepted those rights and interests disposal. According to the International Law of "Relative Effect of Treaties", there is no restraint to China.

\section{Argumentation on the Priority of Cairo Declaration and Potsdam Declaration from the "Before and After Conflict" Application Rule of Law of Treaties}

Targeted at the Chinese territorial sovereignty occupied by Japan, successive international treaties or relevant international documents consist of legal documentation system, which are logically confirmed. Based on the changes of international situation, the contracting parties have adjusted and changed documents during different periods. Consequently, different treaties perform "conflicts" and "differences" to different extents. Thus, under the premise of following the objective of the entire documentation system, how to master the application rule of treaty conflict is crucial for China to discuss the sovereignty of Diaoyu Island.

From the perspective of "Giving Priority to Charter Obligations" emphasized by Law of Treaties, although San Francisco Peace Treaty and the Okinawa Reversion Treaty were contracted after the Charter of the United Nations came into effect, China and America have the obligations to abide by UN Charter as the original UN members. Japan has also the obligations to abide by UN Charter as member joined in 1956.

Based on the defeat of Japan and the principle of "prohibition of force or threats by force" set by UN Charter, Treaty of Shimonoseki became invalid naturally. As the scope of territories allowed to be preserved by Japan after the defeat and those required to be returned to China, without the specific statement of Chinese legal government or recognition of special amendment, China, America and Japan should conform to the object and core contents of Cairo Declaration and Potsdam Declaration while dealing with relevant territories. As the two international treaties of San Francisco Peace Treaty and the Okinawa Reversion Treaty, they do not conform to regulations of Cairo Declaration or Potsdam Declaration at all.

Above all, according to the application rule of "Before and After Conflict" in Law of Treaties, International Law actually has quite clear specification of the territorial sovereignty of Diaoyu Island. According to the regulations of Cairo Declaration and Potsdam Declaration, Diaoyu Island was 
totally and completely returned to China when Japan officially surrendered after World War II.

\section{Conclusion}

In view of the important role of International Treaties in the history of international relationship, international rules of "freedom", "well-intention" and "Paeta Sunt Servanda" emphasized by the preface of Vienna Convention on the Law of Treaties cannot be forgotten. Moreover, international rule of law has increasingly become stable and normal, it should take the "affirmation of disputes over treaties, just as other international disputes, it should take a peaceful way to solve problems and abide by justice and International Law" as the objective to formulate convention. Territorial disputes involve in essential interests of countries, which cannot be neglected. As a responsible country, under the premise of respecting and following the International Law, China will solve the problems of Diaoyu Island and South China Sea. It is an important route to defend national rights and interests of China by emphasizing and following the international treaty law.

\section{Acknowledgement}

Sponsored by education and research project of young and middle-age teachers of Fujian province in 2016(No. JAS160127).

\section{References}

[1] Edit by Editorial Department of Law Teaching Materials of Department of Justice. Selected Documents of International Relationship History, Beijing: Law Press, 1988:290.

[2] In Miles of Costal Defense Map drawn by Zheng Ruoceng in Ming dynasty, Diaoyu Island was clearly marked within the coastal defense scope of navies. Refer to Ju Deyuan, Rectification of Diaoyu Island: Historical Sovereignty of Diaoyu Islands and Sources of International Law, Beijing: Kunlun Press, 2006: 114-122.

[3] Edit by Editorial Department of Law Teaching Materials of Department of Justice. Selected Documents of International Relationship History, Beijing: Law Press, 1988:859.

[4] Refer to "Location Map of Diaoyu Island and Affiliated Islands”,published by National Oceanic and Atmospheric Administration on March 2nd, 2012. 